\title{
WYKAZ PUBLIKACJI PROFESORA ANTONIEGO JACKOWSKIEGO
}

\section{PROFESSOR ANTONI JACKOWSKI: LIST OF PUBLICATIONS}

\section{MONOGRAFIE. PODRĘCZNIKI}

1. Metodyka badań statystycznych ruchu turystyczno-wypoczynkowego i zwiazanych z nim dziedzin życia gospodarczego, WUS, Kraków 1968, ss. 44 + tabl. 35 [współautorstwo: J. Warszyn்ska, J. Bukowski].

2. Turystyka $w$ regionie krakowskim. Nauka dla Wszystkich, $\mathrm{nr}$ 152, PAN Oddział w Krakowie, Kraków 1971, ss. 41 [współautorstwo: J. Warszyńska].

3. Podstawy geografii turyzmu, PWN, Warszawa 1978, dodruk 1979, ss. 333 [współautorstwo: J. Warszyńska].

4. Turystyka $w$ Zwiazku Radzieckim, „Ruch Turystyczny. Monografie, Biuletyn” 1979, z. 19, Ss. 124 .

5. Typologia funkcjonalna miejscowości turystycznych (na przykładzie województwa nowosadeckiego), „Rozprawy Habilitacyjne”, nr 53, Uniw. Jagielloński, Kraków 1981, ss. 137.

6. Zarys geografii pielgrzymek, „Zeszyty Naukowe UJ” 1991, Prace Geograficzne, z. 85, ss. 230.

7. Pielgrzymki i turystyka religijna $w$ Polsce, 1991, Inst. Turystyki, Warszawa, ss. 183.

8. Geografia turystyczna świata [współautorstwo], cz. I i II, red. J. Warszyńska, PWN, Warszawa 1994-1995; [Rozdziały: Belgia, Francja, Holandia, Luksemburg, Monako (cz. I), Filipiny, Japonia (cz. II); współautorskie: Polska (z J. Warszyńska), Białoruś, Estonia, Litwa, Łotwa. Mołdawia, Rosja, Ukraina (z R. Janiec, cz. I), Armenia, Azerbejdżan, Gruzja, Kazachstan, Kirgistan, Tadżykistan, Turkmenistan, Uzbekistan (z R. Janiec, cz. II)].

9. Przestrzeń $i$ sacrum. Geografia kultury religijnej $w$ Polsce $i$ jej przemiany $w$ okresie od XVII do XX w. na przykładzie ośrodków kultu i migracji pielgrzymkowych, Inst. Geografii UJ, Kraków 1995, wyd. 2, Kraków 1996 [współautorstwo: A. Witkowska, Z. S. Jabłoński, I. Sołjan, E. Bilska]; [Rozdziały: Rozwój pielgrzymek w Polsce, s. 13-44; Współczesne migracje pielgrzymkowe w Polsce, s. 45-86].

10. Jasna Góra. Międzynarodowe centrum ruchu pielgrzymkowego, Wyd. Educator, Podyplomowe Studium „Pielgrzymki. Turystyka Religijna”, Skrypt nr 1, Częstochowa 1996, ss. 63.

11. Pielgrzymowanie, ser. A to Polska Właśnie, Wyd. Dolnoślaskie, Wrocław 1998, ss. 312.

12. Jasnogórskie pielgrzymki $w$ przestrzeni miasta i regionu Częstochowy, Inst. Geografii UJ, Kraków 1998, ss. 144 [współautorstwo: D. Ptaszycka-Jackowska].

13. Religie świata. Szlaki pielgrzymkowe, [hasło w:] Wielka encyklopedia świata, t. XV, Wyd. Kurpisz, Poznań 1999, ss. 359, [współautorstwo: I. Sołjan, E. Bilska-Wodecka].

14. Pielgrzym Polski, red. A. Zembik, Stow. Nasza Częstochowa, Częstochowa 2000, ss. 111 [współautorstwo: I. Sołjan].

15. Jasna Góra, ser. A to Polska Właśnie, Wyd. Dolnośląskie, Wrocław 2001, ss. 236 [współautorstwo: J. Pach, J. S. Rudziński].

16. Święta przestrzeń świata. Podstawy geografii religii, Wyd. UJ, Kraków 2003, ss. 268. 


\section{SKRYPTY I BIBLIOGRAFIE}

1. Bibliografia turystyki polskiej 1900-1944, Zakład Zagospodarowania Turystycznego GKKFiT, Wrocław 1968, ss. 183.

2. Bibliografia turystyki polskiej 1945-1960, Zakład Zagospodarowania Turystycznego GKKFiT, Wrocław 1969, ss. 246.

3. Bibliografia turystyki polskiej 1961-1965, Zakład Zagospodarowania Turystycznego GKKFiT, Wrocław 1970, ss. 285.

4. Polska literatura turystyczna 1945-1968. Bibliografia adnotowana wybranych pozycji dla celów dydaktyczno-szkoleniowych, Centralny Ośrodek Doskonalenia Kadr Kultury Fizycznej i Turystyki, Warszawa 1970, ss. 222 [wspólautorstwo: D. Ptaszycka-Jackowska].

5. Bibliografia turystyki polskiej. Biografie 1800-1970, Studia i Materiały, GKKFiT, Zakład Zagospodarowania Turystycznego, Wrocław 1971, ss. 170.

6. Bibliografia turystyki polskiej 1800-1899, Zakład Zagospodarowania Turystycznego GKKFiT, Inst. Turystyki, Wrocław 1972, ss. 222.

7. Bibliografia turystyki polskiej do roku 1972. (Wybór), Inst. Turystyki, Warszawa 1973, ss. 304.

8. Polska literatura turystyczna 1945-1972. Bibliografia adnotowana wybranych pozycji dla celów dydaktyczno-szkoleniowych, Inst. Turystyki, Warszawa 1973, ss. 198 [współautorstwo: D. Ptaszycka-Jackowska].

9. Bibliografia turystyki polskiej 1966-1970, cz. 1, Inst. Turystyki, Warszawa 1975, ss. 280 [współautorstwo: I. Krupianka].

10. Regionalna geografia turystyczna świata, cz. I. Europa i ZSRR, cz. II. Kraje pozaeuropejskie, red. J. Warszyńska, Skrypty Uczelniane, nr 578, 631, Uniw. Jagielloński, Kraków 1988-1990: [cz. I: autorstwo rozdziałów: Francja (s. 79-100), Monako (s. 100-102), Belgia (s. 252-258), Holandia (s. 258-263), Luksemburg (s. 263-265), Zwiazek Radziecki (s. 399-430); cz. II: Filipiny (s. 148151), Japonia (s. 179-187)].

11. Turystyka pielgrzymkowa, Wyd. Centrum Edukacji Kadr Turystycznych, Kraków 1998, s. 1-151 [współautorstwo].

\section{ARTYKUEY, ROZDZIAEY W PRACACH ZBIOROWYCH}

1. Przemyst szklarski $w$ Polsce, „Zeszyty Naukowe UJ” 1961, Prace z Geografii Ekonomicznej, z. 2 , s. 53-70.

2. Przeptywy pieniężne jako przedmiot badań geograficzno-gospodarczych (na przykładzie powiatu Nowy Targ), „Folia Geographica” 1969, ser. Geographica-Oeconomica, vol. 2, s. 125-147.

3. Turystyka $w$ regionie krakowskim, [w:] Baza turystyczna i jej wykorzystanie w regionie krakowskim w 1968 r., WUS, Kraków 1969, s. 12-50 [współautorstwo: J. Warszyńska].

4. Turystyka urlopowa we Francji, „Ruch Turystyczny” 1971, z. 1-2, s. 53-83.

5. Wpływ turystyki na kształtowanie się dochodów ludności powiatu Nowy Targ, „Folia Geographica" 1971, ser. Geographica-Oeconomica, vol. 4, s. 93-112.

6. Turystyka jako element gospodarki Podhala (Studium z geografii turyzmu), „Dokumentacja Geograficzna" 1972, z. 6, s. 132-136.

7. Rozwój geografii turyzmu w Polsce, „Zeszyty Naukowe UJ” 1974, Prace Geograficzne, z. 38, s. 21-49.

8. Rozwój nauki o turyzmie $w$ Zwiazku Radzieckim (Zarys problematyki $w$ świetle wybranych pozycji literatury), „Ruch Turystyczny” 1974, z. 3-4, s. 29-48.

9. Turystyka $w$ makroregionie południowym, „Studia nad Ekonomika Regionu” 1974, z. 5, s. 280-293 [współautorstwo: J. Warszyńska].

10. Turystyka $w$ regionie Langwedocja-Roussillon, „Ruch Turystyczny” 1975, z. 2, s. 153-178 [współautorstwo: D. Ptaszycka-Jackowska].

11. Développement des recherches géographico-touristiques dans les Carpates Polonaises, [w:] Geography of Tourism and Recreation, XXIII International Geographical Congress, Moskva 1976, s. $170-174$. 
12. The influence of tourism on village settlement units in the Podhale region, „Zeszyty Naukowe UJ" 1976, Prace Geograficzne, z. 43, s. 173-185.

13. L'attrait touristique du milieu naturel et le développement de la fonction touristique au niveau de la localité et de la région, [w:] Zagadnienia termiologii $w$ geografii turyzmu, Wyd. UJ, Kraków 1976, s. 64-69 [współautorstwo: J. Warszyńska].

14. Le tourisme comme l'objet des recherches de la géographie du tourisme, [w:] Zagadnienia terminologii w geografii turyzmu, Wyd. UJ, Kraków 1976, s. 69-73 [współautorstwo: J. Warszyńska].

15. Influence du tourisme sur l'habitat rural du bassin de Podhale, [w:] Transformation of rural areas, Inst. Geografii PAN, Warszawa 1978, s. 84-93.

16. Typologia miejscowości turystycznych ze szczególnym uwzględnieniem obszarów górskich, „Folia Geographica” 1978, ser. Geographica-Oeconomica, vol. 11, s. 137-147.

17. Funkcja uzdrowiskowa i turystyczna regionu muszyńskiego, „Zeszyty Naukowe UJ” 1979 , Prace Historyczne, z. 60, s. 149-193 [współautorstwo: J. Warszyńska].

18. Provision for recreation within the conurbation of the Upper Silesian Industrial District (GOP), „Wiener Geographische Schriften” 1979, Heft 53-54, Beiträge zur Fremdenverkehrsgeographie, 2 Teil, s. 159-161 [współautorstwo: J. Warszyńska].

19. Typologia funkcjonalna jednostek administracyjnych województwa nowosadeckiego. „Zeszyty Naukowe AWF w Krakowie" 1979, nr 20, s. 20-29.

20. Wybrane zagadnienia z geografii turyzmu [wojew. miejskiego krakowskiego], „Folia Geographica" 1979, ser. Geographica-Oeconomica, vol. 12, s. 107-121 [współautorstwo: J. Warszyńska].

21. Methodical problems of functional typology of tourist localities ...Folia Geographica” 1980, ser. Geographica-Oeconomica, vol. 13, s. 85-91.

22. Badania w zakresie geografii turyzmu. Uniwersytet Jagielloński. Instytut Geografii. Zakład Geografii Turyzmu, „Zeszyty Naukowe UJ” 1981, Prace Geograficzne, z. 54, s. 19-36.

23. Ruch turystyczny $w$ rejonie zbiorników wodnych rożnowskiego $i$ czchowskiego, „Problemy Zagospodarowania Ziem Górskich" 1981, z. 21, s. 249-258 [współautorstwo: A. Karafiat].

24. The level of research in Poland into reservoir influence on socio-economic and environmental phenomena, „Beiträge zur Hydrologie” 1982, Sonderheft 3, s. 333-341.

25. Problems of tourism in the urban voivodship of Cracow, [w:] Tourisme et loisir aux environs de grandes villes, International Geographical Union - Commission of the Geography of Tourism and Leisure, Łódź 1983, s. 43-65 [współautorstwo: J. Warszyńska].

26. Typologie fonctionnelle des localités touristiques de la Voivodie de Nowy Sacz, „Geographia Polonica"1984, vol. 49, s. 139-148.

27. Wpływ zbiorników retencyjnych na strukture społeczno-gospodarcza ich otoczenia, „Czasopismo Geograficzne" 1984, R. 55, z. 3, s. 379-386.

28. Le développement du tourisme à Cracovie, [w:] Grosstadttourismus, Berlin 1986, s. 213-215 [współautorstwo: J. Warszyńska].

29. Przydatność środowiska przyrodniczego GOP dla rozwoju turystycznych form rekreacji, [w:] Wpływ środowiska przyrodniczego na zróżnicowanie turystycznych form rekreacji, AWF, Warszawa 1986, s. 131-156 [wspólautorstwo].

30. Studies on the Geography of Tourism, „Annals of Tourism Research”, 1986, New York. Pergamon Press INC, s. 655-658 [współautorstwo: J. Warszyńska].

31. Geography of Pilgrimage in Poland, [w:] Trends in the Geography of Pilgrimages. Homage to David E. Sopher, Nat. Geogr. Society of India. Banaras Hindu University, Varanasi 1987, s. 7077; toż w: „National Geographical Journal of India” 1987, vol. 33, no 4, s. 422-429.

32. Les problèmes principales de la géographie des pèlerinages, „Geografia” [Roma], 1987, vol. X, no 1, s. 79-86.

33. Rozwój badań z zakresu geografii turyzmu w ośrodku krakowskim w latach 1945-1985, „Folia Geographica" 1987, ser. Geographica-Oeconomica, vol. 20, s. 95-110 [współautorstwo: J. Warszyniska].

34. Turystyka i pielgrzymki religïne ,„Problemy Turystyki” 1987, nr 1 (35), s. 28-44; toż: Tourisme et pèlerinage religieux. „Problems of Tourism” 1987, nr 1 (35), s. 37-53.

35. Turystyka pielgrzymkowa $w$ krajach islamu, „Zeszyty Naukowe UJ” 1987, Prace Geograficzne, z. 70, s. 147-166.

36. Wybrane problemy turystyki pielgrzymkowej, „Zeszyty Naukowe UJ” 1987, Prace Geograficzne", z. 68, s. 69-86. 
37. Historia turystyki pielgrzymkowej $w$ Polsce, [w:] Turystyka jako czynnik rozwoju społeczno-gospodarczego, Inst. Turystyki, Warszawa 1989, s. 314-327.

38. History of Tourism in Polish Carpathians, „Zeszyty Naukowe UJ” 1989, Prace Geograficzne”, z. 80 , s. $75-83$.

39. Wybrane problemy geografii pielgrzymek $w$ Polsce, „Folia Geographica” 1989, ser. Geographica-Oeconomica, vol. 22, s. 11-37.

40. Pielgrzymki $w$ Polsce a pielgrzymki na świecie, „Problemy Turystyki” 1990, nr 1-2 (47-48), s. 54-65.

41. Basic Research Problems of the Geography of Pilgrimage, „Geografia” [Roma], 1990, vol. XIII, no 1, s. 36-42.

42. Pielgrzymki $w$ Polsce na tle pielgrzymek $w$ chrześcijaństwie, „Jasna Góra” 1990, R. 8, nr 6, s. 44-53.

43. Development of Pilgrimages in Poland. Geographical-Historical Study, [w:] Pilgrimages Studies: Text and Context, Pilgrimage Studies II, The Society of Pilgrimages Studies, Allahabad 1990, s. 242-250.

44. Principalos aspectos de la geografia de las peregrinaciones, Servicio de Documentation, Santiago de Compostela, „Peregrino” 1990, no 17, s. 6-7.

45. Les conditions du développement des pèlerinages dans le Massiff Central et Carpates Polonaises, [w:] Le développement régional en moyenne montagne Carpates et Massif Central, CERAMAC, Clermont-Ferrand 1991, s. 172-178.

46. Les pèlerinages en Pologne comme le phénomène spatial et social, [w:] La lettura geografica, il linguaggio geografico i contenuti geografici a servizio dell'uomo, vol. 2, Patron Editore, Bologna 1991, s. 385-409.

47. Pilgrimages as research object of geography of iourism, „Zeszyty Naukowe UJ” 1991. Prace Geograficzne, z. 86, s. 75-79.

48. Pielgrzymki jako przedmiot badań geograficznych, „Przegląd Religioznawczy” 1992, z. 2 , s. 63-74.

49. Pilgrimage Centres in Poland, „Turyzm” 1992, z. 1, s. 99-111.

50. Studium Turyzmu Uniwersytetu Jagiellońskiego (1936-1939). Zarys działalności dydaktycznej i naukowej, [w:] Studium Turyzmu Uniwersytetu Jagiellońskiego (1936-1939), „Zeszyty Naukowe UJ" 1992, Prace Geograficzne, z. 89, s. 39-59.

51. Certains aspects de la géographie de la religion dans la Pologne du Sud-Est jusqu'en 1939. [w:] Regions Paysannes aux Espaces Fragiles, Univ. Blaise Pascal, Clermont-Ferrand 1992, s. 671-678 [wspólautorstwo: M. Soja].

52. Polish Pilgrim-Tourists, „Annals of Tourism Research” 1992, vol. 19, no 1, s. 92-106 [współautorstwo: V. L. Smith].

53. Pielgrzymki i turystyka religijna w Polsce, [w:] Współczesna turystyka religïna, Polsko-Francuskie Seminarium Turystyczne, Częstochowa 1994, s. 51-58.

54. Wspótczesne tendencje rozwoju ruchu pielgrzymkowego, [w:] Wspótczesna turystyka religijna, Polsko-Francuskie Seminarium Turystyczne, Częstochowa 1994, s. 75-79.

55. Geography of Pilgrimage in the Twenty-First Century: A Forecast, [w:] The Future of Religion. East and West, Inst. Religioznawstwa UJ, Kraków 1995, s. 218-228.

56. Kalwaria Zebrzydowska $w$ sieci ośrodków pielgrzymkowych $w$ Polsce i iv Europie, [w:] Tradycje, wspótczesność i przyszłość pielgrzymek w Kalwarii Zebrzydowskiej, „Peregrinus Cracoviensis" 1995, z. 2, s. 65-75.

57. Ośrodki kultu religijnego, [w:] Karpaty Polskie. Przyroda, człowiek i jego dziatalność, red. J. Warszyńska, Inst. Geografii UJ, Kraków 1995, s. 197-206.

58. Pielgrzymki $w$ polskim prawosławiu, „Turyzm”, 1995, t. 5, z. 2, s. 49-64 [współautorstwo: I. Sołjan].

59. Le développement des centres des pèlerinage dans les Carpates (du XIème au XXème siècle), [w:] Milieu naturel et activités socio-économique dans les montagnes (Carpates-Massif Central), Inst. Geografii UJ, Kraków 1995, s. 137-146, [współautorstwo: I. Sołjan,A. Marciniak].

60. Pielgrzymki i turystyka religijna, „Rocznik Dydaktyczny. Wyższa Szkoła Turystyki i Hotelarstwa w Warszawie", 1996, s. 27-33.

61. Les centres de culte religieux dans les Carpates Polonaises, [w:] Recherches de Géographie Humaine, Societè Géographique de Liège, Liège 1996 s. 79-83 [współautorstwo: I. Sołjan, E. Bilska]. 
62. Jasna Góra w systemie ośrodków pielgrzymkowych świata, [w:] Jasna Góra. Światowe centrum pielgrzymkowe, „Peregrinus Cracoviensis” 1996, z. 3. s. 171-191 [współautorstwo: L. Kaszowski]; toż: Jasna Góra in the system of world pilgrimage centers, [w:] Jasna Góra. The World Centre of Pilgrimage, Kraków 1996, s. 171-190.

63. Jasna Góra na tle innych ośrodków pielgrzymkowych w Polsce, [w:] Jasna Góra. Światowe centrum pielgrzymkowe, „Peregrinus Cracoviensis” 1996, z. 3, s. 153-170 [współautorstwo: I. Sołjan]; toż: The Jasna Góra Sanctuary against the background of the other pilgrimage centres in Poland, [w:] Jasna Góra. The World Centre of Pilgrimage, tamże.

64. Geografia religii - problemy badawcze, perspektywy rozwoju, [w:] Geografia. Człowiek. Gospodarka, Inst. Geografii UJ, Kraków 1997, s. 85-94 [współautorstwo: I. Sołjan, E. Bilska].

65. Geografia pielgrzymek Jana Pawta II, [w:] Jan Pawet II - „Pielgrzym pośród pielgrzymów”, „Peregrinus Cracoviensis” 1997, z. 5, s. 39-60 [współautorstwo].

66. Pielgrzymki a gospodarka turystyczna, [w:] Turystyka $w$ rozwoju regionalnym, Inst. Turystyki, Kraków 1997, s. 57-69.

67. Piesze pielgrzymki na Jasna Góre, „Peregrinus Cracoviensis” 1998, z. 6, s. 211-234 [współautorstwo: D. Ptaszycka-Jackowska, U. Gospodarek].

68. Pielgrzymki $=$ turystyka pielgrzymkowa $=$ turystyka religijna? Rozważania terminologiczne, „Turyzm”, 1998, t. 8, z. 1, s. 5-20.

69. Jasna Góra a przestrzenna struktura kultu maryjnego na terytorium Polski przed II wojna światowa, „Studia Claromontana” 1998, t. 18, s. 5-26 [wspólautorstwo: L. Kaszowski, I. Sołjan].

70. Pielgrzymki do sanktuariów maryjnych jako jeden z czynników integracji Wschodu z Zachodem, [w:] Nosicielka Ducha Pneumatofora, Red. Wydawnictw KUL, Lublin 1998, s. 361-369.

71. Maryjne Karpaty, [w:] Pani ziemi tarnowskiej. Sanktuarium Matki Bożej w Tuchowie 15971997. Ksiega Jubileuszowa, Wyd. Pol. Tow. Teologiczne, Kraków 1998, s. 25-40 [współautorstwo: I. Sołjan].

72. Jubileusz geografii krakouskiej, [w:] Geografia w Uniwersytecie Jagiellońskim. 1849-1999, t. I, Inst. Geogr. UJ, Kraków 1999, s. 13-30 [współautorstwo: B. Kortus, K. Krzemień].

73. Ruch pielgrzymkowy na Jasna Górę $w$ okresie pontyfikatu Jana Pawta II, [w:] Jasna Góra w 20-leciu pontyfikatu Jana Pawta II, Jasna Góra-Częstochowa 1999, s. 232-248 [współautorstwo: D. Ptaszycka-Jackowska].

74. Geografia religii, [w:] Geografia $w$ Uniwersytecie Jagiellońskim. 1849-1999, t. III, Inst. Geografii UJ, Kraków 1999, s. 433-457 [współautorstwo I. Sołjan, E. Bilska-Wodecka].

75. Leżajsk $w$ sieci ośrodków pielgrzymkowych Polski, [w:] Czterysta lat Sanktuarium Matki Bożej Pocieszenia w Leżajsku, „Peregrinus Cracoviensis” 1999, z. 7, s. 113-124 [współautorstwo: I. Sołjan].

76. Ośrodki turystyki religijnej $w$ Poisce i perspektywy ich rozwoju, „Turyzm” 1999, t. 9, z. 1, s. 91-103 [współautorstwo: I. Sołjan, E. Bilska].

77. Obiekty sakralne jedna z szans rozwoju polskiej turystyki, [w:] Turystyka w obiektach zabytkowych $i$ sakralnych, Górnośląska Wyższa Szkoła Handlowa, Inst. Turystyki, Kraków 1999, s. 91-99.

78. Turystyka religijna - problemy terminologiczne, [w:] Turystyka w obiektach zabytkowych i sakralnych. Górnośląska Wyższa Szkoła Handlowa, Inst. Turystyki, Kraków 1999, s. 101-116.

79. A montana sacrada de Grabarka. O corazón da igrexa ortodoxa Polaca, [w:] Grabarka. O Monte des 6.000 Cruces. Unha peregrinación ortodoxa en Polonia, red. C. G. Rodero, Museo das peregrinacións. Santiago de Compostela 2000, s. 23-30; toż: El monte sagrado de Grabarka. El corazón de la iglesia ortodoxa polaca, s. 31-38, toż: The Holy Mount of Grabarka. The Heart of the Polish orthodox Church, s. 129-134.

80. Łagiewniki $w$ systemie ośrodków pielgrzymkowych Polski $i$ świata. [w:] Nowy klejnot $w$ koronie Krakowa, red. A. Jackowski, I. Sołjan, „Peregrinus Cracoviensis” 2000, s. 145-155, z. 9; toż: Łagiewniki in the system of Poland's and the World's Pilgrimage Centres, [w:] A New Jewel in the Crown of Cracow, red. A. Jackowski, I. Sołjan, „Peregrinus Cracoviensis” 2001, z. 11, s. 143-152.

81. Religinus Tourism - Problems with Terminology, [w:] Selected research problems in the Geography of Pilgrimage, red. A. Jackowski, I. Sołjan, „Peregrinus Cracoviensis” 2000, z. 10, s. 63-74.

82. Środowisko geograficzne $w$ religiach świata, [w:] Przyroda-nauka-kultura. Humanistyczny kontekst nauk przyrodniczych u progu XXI wieku, red. B. Zemanek, Inst. Botaniki PAN, Kraków 2000, s. 189-201. 
83. Turystyka religijna na Podkarpaciu, [w:] Kierunki aktywizacji gospodarczej przez turystyke na obszarach przygranicznych, Materiały z międzynarodowej konferencji 20-21.03.2000 r. w Krośnie, Krosno 2000, s. 88-94.

84. Gtówne trasy pielgrzymek pieszych na Jasna Górę [mapa], [w:] Atlas Polski, red. W. Maciejowski, R. Uliszak, Wyd. Opres, Krakỏw 2000, s. 82.

85. Pielgrzymki Jana Pawła II [mapa], [w:] Atlas Polski, red. W. Maciejowski, R. Uliszak, Wyd. Opres, Kraków 2000, s. 82 [współautorstwo: E. Bilska-Wodecka, A. Marciniak, I. Sołjan].

86. Ruch pielgrzymkowy $w$ ośrodkach kultu religijnego (1999) [mapa], [w:] Atlas Polski, red. W. Maciejowski, R. Uliszak, Wyd. Opres, Kraków 2000, s. 81 [współautorstwo: E. Bilska-Wodecka, A. Marciniak, I. Sołjan].

87. The Holy Mount of Grabarka - the Heart of the Polish Orthodox Church, [w:] Selected research problems in the Geography of Pilgrimage, red. A. Jackowski, I. Sołjan, „Peregrinus Cracoviensis" 2000, z. 10, s. 207-218 [współautorstwo: A. Marciniak].

88. Milenium polskiego pielgrzymouvania. „Peregrinus Cracoviensis” 2000, z. 8, s. 9-38 [współautorstwo: I. Sołjan]; toż: The Millennium of Polish Pilgrimages, [w:] Selected research problems in the Geography of Pilgrimage, red. A. Jackowski, I. Sołjan, „Peregrinus Cracoviensis” 2000, z. 10, s. 111141 [współautorstwo: I. Sołjan].

89. Polskie pielgrzymowanie, [w:] Ziemia. V Kongres Krajoznawstwa Polskiego 8-10 września 2000, Wyd. Zarząd Główny PTTK, „Ziemia 2000”, Warszawa 2000, s. 251-268.

90. Fenomen pielgrzymowania na Jasna Góré trwatym elementem polskiej religijności $i$ kultury. [w:] Rycerze Jasnogórskiej Bogarodzicy. Etos Jasnej Góry - rycerska tradycja i posłanie, red. A. A. Napiórkowski, Wyd. Paulinianum, Częstochowa-Jasna Góra 2001, s. 39-48.

91. Integracyjna rola pielgrzymek do sanktuariów zakonnych, [w:] Klasztory i kultura krajów stowiańskich, red. W. Stępniak-Minczewa, Z. J. Kijas OFMConv., Papieska Akad. Teologiczna, Kraków 2001, s. 111-119 [współautorstwo: I. Sołjan].

92. Środowisko przyrodnicze $w$ religiach świata, [w:] Pielgrzymki jako element kultury religijnej, red. A. Jackowski, I. Sołjan, „Peregrinus Cracoviensis” 2001, z. 12, s. 11-20 [współautorstwo: I. Sołjan].

93. Geography of Religion, [w:] Sacred Geography, red. A. Jackowski, I. Soljan, „Peregrinus Cracoviensis" 2002, z. 13, s. 25-34.

94. Szlaki pielgrzymkowe jako element integracji Europy, [w:] Europejskie Dni Dziedzictwa, Oddział PTTK, Kraków 2002, s. 55-71.

95. Le système mondial des centres de pèlerinage, [w:] Santuario spazio per un'accoglienza fraterna e universale. Atti del $3^{\circ}$ Congresso Europeo sui Santuari e i Pellegrinaggi, Montserrat, Spagna, 4-7 marzo 2002, Pontificio Consiiglio Della Pastorale Per i Migranti e Gli Itineranti, Santuario Nostra Signora Di Montserrat, Città del Vaticano 2002, s. 115-126 [wspólautorstwo: D. Ptaszycka-Jackowska, I. Sołjan].

96. Kalwaria Zebrzydowska $w$ systemie ośrodków pielgrzymkowych świata i Polski, [w:] Kalwaria Zebrzydowska - polska Jerozolima skarbem Kościoła i narodu polskiego, red. Cz. Gniecki OFM, Wyd. Calvarianum, Kalwaria Zebrzydowska 2002, s. 485-494 [współautorstwo: I. Sołjan].

97. Nature vs. Sacrum in the World's Religions, [w:] Sacred Geography, red. A. Jackowski, I. Sołjan, „Peregrinus Cracoviensis” 2002, z. 13, s. 193-208 [współautorstwo: I. Sołjan].

98. Światowy system ośrodków pielgrzymkowych, „Turyzm”, 2002, t. 12, z. 2, s. 51-63 [współautorstwo: D. Ptaszycka-Jackowska, I. Sołjan].

99. Ośrodki patnicze i pielgrzymkowe $w$ województwie podkarpackim. „Przegląd Kalwaryjski” 2003 , t. 8 , s. $173-182$.

100. Pielgrzymki oraz turystyka religijna - problemy terminologiczne, [w:] Turystyka a religia, red. J. Bergier, J. Żbikowski, Wyd. PWSZ, Biała Podlaska 2003, s. 11-34.

101. Pilgrimaging in the history of Polish tourism, [w:] Issues of tourism and health resort management, red. W. Kurek, „Prace Geograficzne”, z. 111, Kraków 2003, s. 247-260.

102. Turystyka religijna jako element integracji europejskiej, [w:] Unia Europejska a przyszłość polskiej turystyki, Szkoła Główna Handlowa, Warszawa 2003, s. 125-136 [współautorstwo: I. Soljan].

103. Gietrzwałd $w$ systemie ośrodków pielgrzymkouych Europy i Polski, [w:] Maryjne orędzie z Gietrzwałdu, Polskie Towarzystwo Mariologiczne, Częstochowa-Gietrzwałd 2003, s. 79-90 [wspó1autorstwo: I. Sołjan]. 
104. Mapy $w$ turystyce religijnej na przykładzie Jerozolimy, sacri monti, kaluarii $i$ Santiago de Compostela, [w:] Kartografia $w$ turystyce - turystyka $w$ kartografii, Inst. Geografii i Gospodarki Przestrzennej UJ, Kraków 2003, s. 31-39 [współautorstwo: E. Bilska-Wodecka].

105. Pielgrzymowanie $w$ Archidiecezji Krakowskiej. [w:] Archidiecezja Krakowska na przełomie tysiącleci, Uniw. Jagielloński, Papieska Akad. Teologiczna, Kraków 2004, s. 249-256 [współautorstwo: I. Sołjan].

106. Swietta przestrzeń świaia. The World's Sacred Space, [w:] Miejsca duchowe, Wydz. Architektury Politechniki Warszawskiej, Warszawa 2004, s. 31-37.

107. Jan Dtugosz jako geograf, [w:] Przyroda - człowiek - Bóg, red. B. Izmaiłow, Wyd. Inst. Geografii i Gospodarki Przestrzennej UJ, Kraków 2004, s. 253-262 [współautorstwo: I. Sołjan].

108. Szkoty geograficzne $w$ Uniwersytecie Jagiellońskim, [w:] Geografia u progu XXI wieku, Wyd. Komitet Nauk Geograficznych PAN, Inst. Geografii i Gospodarki Przestrzennej UJ, Kraków 2004.

\section{INNE PUBLIKACJE}

1. Kilka uwag o bibliografiach z zakresu geografii gospodarczej, „Zeszyty Naukowe UJ” 1963, Prace Geograficzne, z. 6, s. 53-68.

2. Mapy z zakresu przemysłu [4], [w:] Atlas świata, Służba Topograficzna WP, PWN, Warszawa 1967.

3. Stownik ekonomiczno-geograficzny. Materiat dla studentów i nauczycieli geografii, WSP w Krakowie, Kraków 1969 [hasła z geografii turyzmu].

4. Polska literatura krajoznawcza, „Nowa Szkoła” 1971, nr 7-8, s. 114-117.

5. Plan kierunkowy zagospodarouania turystycznego Polski. Założenia i podstawowe ustalenia planu, Zakład Zagospodarowania Turystycznego, GKKFiT, Wrocław 1971 [współautorstwo].

6. Gospodarcze funkcje turystyki $w$ powiecie Nowy Targ. „Sprawozdania z Posiedzeń Komisji Naukowych, Oddział PAN w Krakowie" 1971, t. XV, z. 1, s. 209-210.

7. [Gospodarka turystyczna w powiecie Nowy Targ], „Problemy Ekonomiczne” 1972, nr 2/42, s. $86-87$.

8. [Ekonomiczne problemy turystyki], „Problemy Ekonomiczne” 1973, nr 1/45, s. 123-124.

9. [Statystyka turystyki], „Statystyk Terenowy” 1973, nr 9, s. 8-9.

10. Kartograficzny obraz turystyki województwa krakowskiego. [w:] Problemy kartografii turystycznej, PTG, Warszawa 1973, s. 39-43 [współautorstwo: J. Warszyńska].

11. Sympozjum geografii turyzmu, „Biuletyn Informacyjny Inst. Turystyki” 1974, nr 8-9, s. 6768 [współautorstwo: J. Warszyńska].

12. Rozwój polskiej geografii turyzmu, [w:] Problemy turystyki zagranicznej. Materiały z Sympozjum Naukowego $w$ Stulecie Zorganizowanej Turystyki Polskiej, Zakopane 19-21 października 1973, AWF, Kraków 1975, s. 273-275.

13. Międzynarodowe Sympozjum „Zagadnienia terminologii $w$ geografii turyzmu” oraz posiedzenie Grupy Roboczej Geografii Turyzmu Międzynarodowej Unii Geograficznej (MUG), Kraków-Zakopane, 7-10 XI 1974 r., „Ruch Turystyczny” 1976, z. 1-2, s. 142-145.

14. Développement de la géographie du tourisme en Pologne, [w:] Proceedings of the $6^{\text {th }}$ International Congress of Speleology, vol. VII, Praha 1977, s. 201-204.

15. Bibliografia historii krajoznawstwa i turystyki $w$ Polsce, „Ziemia” 1975/1976, s. 287-307.

16. Wybrane problemy rozwoju Muszyny, [w:] Materiaty z I. Regionalnej Konferencji Naukowej 15-16 kwietnia 1977 r. w Muszynie, Muszyna 1979, ss. 4.

17. Turystyka [Mapy], [w:] Atlas miejskiego województwa krakowskiego, Kraków 1979, s. 40-41 [współautorstwo: J. Warszyńska].

18. Impact of passport facilities in the passenger traffic between Poland and German Democratic Rebublik (GDR) on the development of touristic phenomena. (Abstract), „Frankfurter Wirtschaftsund Sozialgeographische Schriften” 1979, Heft 313, s. 353 [współautorstwo: J. Warszyńska].

19. L'influence du tourisme sur le réseau commercial et gastronomique en Pologne, [w:] Tourisme et commerce. Rôle du tourisme et de la villégiature dans la mise en place et fonctionnement des équipemente commerciaux, Nice 1980, s. 3-8. 
20. Rec.: M. Bonneau: Le fait touristique dans la France de l'Ouest: contribution à une recherche sur le tourisme rural, Rennes 1978, „Przeglad Geograficzny” 1980, t. 52, z. 1, s. 229-230.

21. Turystyka [mapy], [w:] Atlas województwa bielskiego, Kraków 1982, s. 36-37 [współautorstwo: J. Warszyńska].

22. Stownik geograficzno-ekonomiczny, Wyd. Nauk. WSP, Kraków 1982 [hasła z geografii tury$\mathrm{zmu}$.

23. Le tourisme de pèlerinage en Pologne. [w:] 25e Congrès International de Géographie, Resumé des Communications, Paris 1984.

24. Wybrane problemy turystyki pielgrzymkowej w Polsce, [w:] Materiaty II. Zjazdu Geografów Polskich, Łódż, 11-13 IX 1985 (streszczenia referatów), Łódż 1985, s. 199-201.

25. Ptaszycki Mieczystaw Jan (1883-1971), geobotanik, geograf, pedagog i działacz społeczny, [w:] Polski stownik biograficzny, t. XXIX/2, z. 121, Wrocław 1986, s. 292-293.

26. Turystyka [mapy], [w:] Atlas m. Krakowa, Kraków 1988, plansza 46 [współautorstwo: J. Warszyńska].

27. Swiat pielgrzymujacy, „Dziennik Polski”, nr 281, Kraków 1990.

28. Instytut Geografii Uniwersytetu Jagiellonskiego w latach 1981-1987, „Zeszyty Naukowe UJ” 1990, Prace Geograficzne, z. 77, s. 109-120 [współautorstwo: I. Dynowska i B. Kortus].

29. Peregrinus... Mundialis?... Polonus?... Cracoviensis?..., „Peregrinus Cracoviensis” 1995, z. 1, s. $11-15$.

30. Sprawozdanie z Konwersatorium Pielgrzymkowego $w$ Kalwarii Zebrzydowskiej, „Peregrinus Cracoviensis" 1995, z. 2, s. 167-168.

31. Wstęp, [w:] Przestrzeń $i$ sacrum. Geografia kultury religijnej $w$ Polsce i jej przemiany $w$ okresie od XVII do XX w. na przykładzie ośrodków kultu i migracji pielgrzymkowych, red. A. Jackowski i inni, Kraków 1995, wyd. II, Kraków 1996, s. 7-12.

32. Profesor Jadwiga Warszyńska - badacz i nauczyciel akademicki, „Turyzm” 1995, t. 5, z. 2, s. .7-11.

33. Polska pielgrzymujaca. Komentarz do wystawy towarzyszacej FORUM, Muzeum Częstochowskie, „Forum Ośrodków Kultu Religijnego”, Częstochowa 15-17.11.1995, Częstochowa 1995, ss. 15.

34. Polska pielgrzymujaca, „Jasna Góra” 1996, R. XIV, z. 2, s. 12-15 [współautorstwo: K. Maniecki].

35. Wstęp, [w:] Jasna Góra światowe centrum pielgrzymkowe, „Peregrinus Cracoviensis” 1996. z. 3, s. 9-13; toż: Introduction, [w:] Jasna Góra the World Centre of Pilgrimage, tamże.

36. Wstęp, „Peregrinus Cracoviensis” 1996, z. 4, s. 7-10.

37. Wstęp, [w:] Jan Pawet II - „Pielgrzym pośród pielgrzymów”, „Peregrinus Cracoviensis” 1997. z. 5, s. 7-8.

38. Hasła, [w:] Miejsca święte, red. Z. Pasek, Wyd. Znak, Kraków 1997.

39. Hasła, [w:] Miejsca święte Rzeczypospolitej, red. A. Jackowski, Wyd. Znak, Kraków 1998.

40. Wstęp, [w:] Miejsca święte Rzeczypospolitej, red. A. Jackowski, Wyd. Znak, Kraków 1998, s. 5-17.

41. Jasna Góra w moim życiu, „Jasna Góra” 1998, nr 5, s. 25-27.

42. Afryka - religie i struktura wyznaniowa. [w:] Przegladowy atlas świata, t. 1, Wyd. Fogra, Kraków 1998 [współautorstwo: I. Sołjan, E. Bilska-Wodecka].

43. Spécifités des pèlerinages en Pologne, [w:] III Międzynarodowy Kongres Miast Pielgrzymkowych, Częstochowa 23-25 września 1999, Urząd Miasta, Częstochowa 1999, s. 98-108.

44. Jubileusz geografii krakowskiej, „Alma Mater” 1999, nr 12 [współautorstwo: B. Kortus, K. Krzemień]; toż: Jubilee of Cracow Geography, tamże.

45. Chrześcijańskie pielgrzymowanie, „Poznaj Świat” 1999, nr 5, s. 4-15.

46. Hasła, [w:] Szlaki pielgrzymkowe Europy - leksykon, red. A. Jackowski, I. Sołjan, Wyd. Znak, Kraków 2000.

47. Wstẹp, [w:] Szlaki pielgrzymkowe Europy - leksykon, red. A. Jackowski, I. Sołjan, Wyd. Znak, Kraków 2000, s. 5-13.

48. Rec.: J. Poniewierski, Pontyfikat, „Peregrinus Cracoviensis” 2000, z. 8, s. 289-290.

49. Pielgrzymowanie, [w:] Przewodnik pielgrzyma 2000, red. M. Boznański, D. Miazga, M. Nowak, M. Westrych, K. Weżranowska, R. Zakrzewski, Wyd. Optimus Pascal SA, Bielsko-Biała 2000, s. $1-6$. 
50. Słowo wstepne, [w:] Rzym. Rok Siwięty 2000, Wyd. Pascal, Bielsko-Biała 2000, s. 8.

51. Pielgrzymujemy od tysiaca lat, „Miesiąc w Krakowie” 2000, $\mathrm{nr} 8, \mathrm{~s}$. 68-69; toż: We have been on pilgrimage for 1000 years, s. 12-13.

52. Rec.: T. Kukiz, Wotyńskie Madonny i inne obiekty sakralne $z$ diecezji tuckiej oraz Madonny kresowe $i$ inne obiekty sakralne z Kresów $w$ diecezji opolskiej, „Peregrinus „Cracoviensis” 2000, z. 8, s. 285-286.

53. Hasła, [w:] Encyclopedia of Tourism, red. J. Jafari, Routledge Ed., London-New York 2000.

54. Turystyka religijna w Polsce, [w:] Forum pielgrzymowania. Konferencja, Częstochowa, 14 września 2001, Meritum Agencja, Częstochowa 2001, s. 16-30 [współautorstwo: I. Sołjan].

55. The past, the present and the perspectives for development of pilgrimages foot in Poland, [w:] Foot pilgrimage: from the past to the future, Sanctuary of Fatima, Fatima 2001 [współautorstwo: L. Kaszowski, I. Sołjan].

56. Religia. Encyklopedia PWN, t. 1, red. T. Gadacz, B. Milerski, Wyd. Nauk. PWN, Warszawa 2001 [Rozdziały: Afryka. s. 74-78; Ameryka Południowa, s. 183-186; Ameryka Pótnocna, s. 186189. Australia i Oceania, s. 407-408; Azja, s. 434-438 wspólautorstwo: E. Bilska-Wodecka, I. Sołjan].

57. Hasła, [w:] Religia. Encyklopedia PWN, red. T. Gadacz, B. Milerski, t. 1-9, Wyd. Nauk. PWN, Warszawa 2001-2003.

58. [Fenomen pielgrzymowania], „Dziennik Polski”, Kraków 2002, 2.07.-16.08.

59. Kalwaria Zebrzydowska $w$ systemie ośrodków pielgrzymkowych świata i Polski, „Pielgrzym Kalwaryjski" 2002, nr 14, s. 33-36.

60. Stowo wstępne. [w:] Jasnogórskie kalendarium Prymasa Polski kardynała Stefana Wyszyńskiego, red. Z. S. Jabłoński OSPPE, Wyd. Zakonu Paulinów, Jasna Góra-Częstochowa 2002 , s. $5-6$,

61. Niezwykty dokument o pieszym pielgrzymowaniu na Jasna Górę w okresie komunizmu, [w:]

$Z$ notatnika pielgrzyma, red. J. Pach, Biblioteka Niedzieli, Częstochowa 2003, s. 9-14.

62. Pielgrzymki do sanktuariów jako element integracji europejskiej, „Pielgrzym Kalwaryjski” 2003, nr 16, s. 23-25.

63. Od Redakcji, [w:] Skałka - Sanktuarium i Panteon Narodu. 750-lecie kanonizacji św. Stanistawa Biskupa i Męczennika, red. L. Kaszowski OSPPE, „Peregrinus Cracoviensis” 2003, s. 11-12, 2. 14 .

64. Matka Boża kierowała naszymi losami, „Cuda i Łaski Boże” 2004, nr 1, s. 14; przedruk "Niedziela" 2004, nr 11, s. 13.

65. Na patniczych szlakach, „Różaniec” 2004, nr 7/8, s. 20-23.

66. Ojciec doc. dr hab. Ludwik Kaszowski, geograf - paulin, [w:] Przyroda-człowiek - Bóg, red.

B. Izmaiłow, Wyd. Instytut Geografii i Gospodarki Przestrzennej UJ, Kraków 2004, s. 13-15.

67. Wstęp, [w:] Encyklopedia geografii, red. A. Jackowski, Wyd. Zielona Sowa, Kraków 2004, s. $9-10$.

68. Hasła, [w:] Encyklopedia geografii, red. A. Jackowski, Wyd. Zielona Sowa, Kraków 2004.

69. Wstęp, [w:] Geografia u progu XXI wieku, Kraków 2004.

70. Jerzy Pokorny, [w:] Kronika Uniwersytetu Jagiellońskiego za rok akademicki 2001/2002. red. A. K. Banach, Kraków 2004, s. 323-324.

\section{REDAKCJE}

1. Główne problemy rozwoju turystyki zimowej w Polsce, Inst. Turystyki, Warszawa 1973.

2. Zagadnienia terminologii w geografii turyzmu. Materiaty Międzynarodowego Sympozjum Kraków-Zakopane 7-10 listopada 1974 r., "Zeszyty Naukowe UJ” 1976, Prace Geograficzne, z. 42 [współredakcja: J. Warszyńska].

3. Problemy badawcze geografii turyzmu $w$ Polsce $w$ latach 1970-1978. Materiaty Sympozjum organizowanego przez Instytut Geografii UJ, Kraków 17-18 XI 1978 r., „Zeszyty Naukowe UJ” 1981, Prace Geograficzne, z. 54 [współredakcja: J. Warszyńska].

4. Studium Turyzmu Uniwersytetu Jagiellońskiego (1936-1939), „Zeszyty Naukowe UJ” 1992,

Prace Geograficzne, z. 89. 
5. „Peregrinus Cracoviensis” 1995, z. 1.

6. Tradycje, współczesność i przyszłość pielgrzymek $w$ Kalwarii Zebrzydowskiej, „Peregrinus Cracoviensis" 1995, z. 2.

7. Przestrzeń $i$ sacrum. Geografia kultury religijnej $w$ Polsce $i$ jej przemiany $w$ okresie od XVII do XX w. na przykładzie ośrodków kultu i migracji pielgrzymkowych, Inst. Geografii UJ, Kraków 1995 , wyd. II, 1996.

8. Jasna Góra - światowe centrum pielgrzymkowe. „Peregrinus Cracoviensis” 1996, z. 3; toż: Jasna Góra. The World Centre of Pilgrimage, tamże.

9. „Peregrinus Cracoviensis”, 1996, z. 4.

10. Jan Pawet II - „Pielgrzym pośród pielgrzymów”, „Peregrinus Cracoviensis” 1997, z. 5.

11. Geografia. Człowiek. Gospodarka, Inst. Geografii UJ, Kraków 1997 [współredakcja: B. Domański].

12. Miejsca święte Rzeczypospolitej, Wyd. Znak, Kraków 1998.

13. „Peregrinus Cracoviensis” 1998, z. 6.

14. Geografia w Uniwersytecie Jagiellońskim. 1989-1999, t. I: Dzieje Katedry i Instytutu Geografii Uniwersytetu Jagiellońskiego, ss. 175; t. II: Wybitni geografowie Uniwersytetu Jagiellońskiego, ss. 279; t. III: Rozwój i dorobek nauk geograficznych $w$ Uniwersytecie Jagiellońskim, ss. 543; Inst. Geografii UJ, Kraków 1999 [współredakcja: B. Kortus, K. Krzemień].

15. Czterysta lat Sanktuarium Matki Bożej Pocieszenia w Leżajsku, „Peregrinus Cracoviensis” 1999, z. 7.

16. „Peregrinus Cracoviensis” 2000, z. 8.

17. Nowy klejnot $w$ koronie Krakowa, „Peregrinus Cracoviensis” 2000, z. 9 [współredakcja: I. Sołjan].

18. Selected Research Problems in the Geography of Pilgrimage, „Peregrinus Cracoviensis” 2000, z. 10 [współredakcja: I. Sołjan].

19. Szlaki pielgrzymkowe Europy - leksykon, Wyd. Znak, Kraków 2000 [współredakcja: I. Sołjan].

20. Geografia $w$ Uniwersytecie Jagiellońskim. 1989-1999, t. V: Nauki geograficzne $w$ poszukiwaniu prawdy o Ziemi i człowieku, ss. 279; Inst. Geografii UJ, Kraków 2000 [współredakcja: B. Kortus, K. Krzemień].

21. A New Jewel in the Crown of Cracow, „Peregrinus Cracoviensis” 2001, z. 11 [współredakcja: I. Sołjan].

22. Pielgrzymki jako element kultury religijnej, „Peregrinus Cracoviensis” 2001, z. 12 [współredakcja: I. Sołjan].

23. Sacred Geography, „Peregrinus Cracoviensis” 2003, z. 13 [współredakcja: I. Sołjan].

24. Encyklopedia geografii, Wyd. Zielona Sowa, Kraków 2004.

25. Geografia u progu XXI wieku, Wyd. Komitet Nauk Geograficznych PAN, Inst. Geografii i Gospodarki Przestrzennej UJ, Kraków 2004. 